
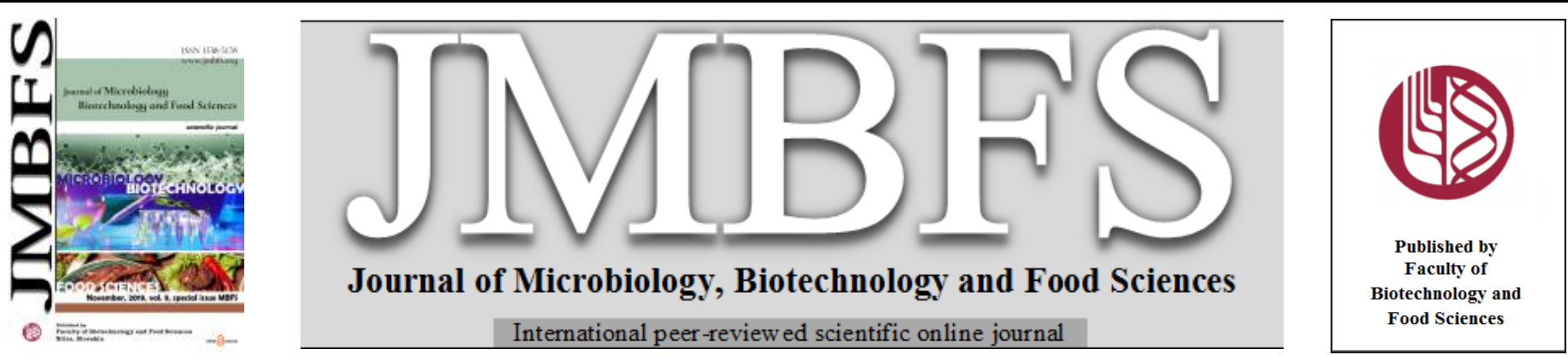

\title{
ANALYSIS OF THE INCIDENCE OF FOREIGN BODIES IN EUROPEAN FOODS
}

\author{
Jozef Čapla, Peter Zajác, Martina Fikselová, Alica Bobková, Lubomír Belej, Veronika Janeková*
}

Address(es): Ing. Jozef Čapla, PhD.

*Department of Food Hygiene and Safety, Faculty of Biotechnology and Food Sciences, Slovak University of Agriculture, Tr. A. Hlinku 2, 94976 Nitra, Slovak Republic.

*Corresponding author: capla@ potravinarstvo.com

doi: 10.15414/jmbfs.2019.9.special.370-375

\section{ARTICLE INFO}

Received 7. 6. 2019

Revised 12.9. 2019

Accepted 13. 9. 2019

Published 8. 11. 2019

Regular article

OPEN 2 ACCESS

\begin{abstract}
This paper contains a comprehensive review of different types of foreign matter reported in Rapid Alert System for Food and Feed (RASFF) during the period 2016 - 2018. It provides information on incidents of foreign matter contamination discussed and mined in terms of types of foreign bodies, food products involved and geographic distribution within indicated European regions. By analysing the presence of foreign bodies in different European regions (Eastern, Northern, Southern, Western Europe), we found, by means of statistical evaluation, that there were differences in some of the data obtained with respect to the country reporting a foreign body. We found that plastic, glass and metal were the most commonly reported in Western Europe, pests and rubber in Northern Europe. As far as food commodities are concerned, bakery and confectionery products, fruit and vegetables and convenience foods were most frequently reported and the notifications came most often from Western Europe. Notifications from this part of Europe were made with regard to other monitored commodities as well. Regarding the notification type, the most frequent one was an alert and, in the case of a risk decision, serious risk constituted the largest part.
\end{abstract}

\section{INTRODUCTION}

The food safety is the main concern of the politicians and inhabitants in whole Europe. According the currently valid legislation the food should be save. The food should be safe from all aspects: chemical, microbiological, physical and radiological (Svrčinová et al., 2019).

Several studies have been conducted in previous years to investigate the level of food safety knowledge among food handlers working in restaurants and catering (Sun et al., 2012; Panchal et al., 2013; Pichler et al., 2014), small businesses (Gomes-Neves et al., 2011), and meat processing plants (Ansari-Lari et al., 2010; Jianu and Golet, 2014). However, there was no such research related to physical contaminants and food safety knowledge among food handlers. Hence foreign bodies can range from items that are demonstrably alien to the food, such as pieces of glass, metal or plastic through items that are related to the food, such as fragments of bone in meat products to part of the food itself, such as crystals of sugar or salt that are mistaken for glass (Edwards, 2014). Metallic foreign bodies can occur in foods as a result of contamination of raw materials and their improper quality control during reception into the plant, improperly conducted production processes, employees' negligence, inadequate state of machines and equipment (Codex Alimentarius, 2014). In many countries the occurrence of foreign bodies is the most common cause of detected defects in foods (Edwards and Stringer 2007). Food manufacturers are very careful when it comes to detection of foreign bodies in food because it can lead to injury to customers. This, in turn, can cause loss of loyalty as well, recalls and rejections. Food safety and quality control are essential parts of the food industry. In practice there should be measures taken by companies to eliminate or reduce the risk of foreign body contamination (Mattos et al., 2016). As a support in assuring safety of food and animal feed on the European market, the European Union (EU) has established the Rapid Alert System for Food and Feed (RASFF) in line with the "General Food Law" (European Union, 2015). This interactive database enables exchange of information regarding measures taken in respect to various aspects of food safety and food fraud (Bouzembrak and Marvin, 2016). The European Commission Maintains the Rapid Alert System for Food and Feed (RASFF) (European Union, 2018). RASFF is an exchange tool on food and feed risk control measures. RASFF data provide useful up-to-date and real-life information for risk analysis. The presence of foreign bodies in food is one of the main problems in food industry and the number of notifications fi led to the Rapid Alert System for Food and Feed (RASFF) con fi rms the importance of the problem (European Union, 2017). In the USA, a study of foreign bodies in food was performed by Mattos et al. (2016). They conclude that although some foreign matter found are considered as unavoidable, further development of control mechanisms should be supported throughout food processing (Djekic et al., 2017)

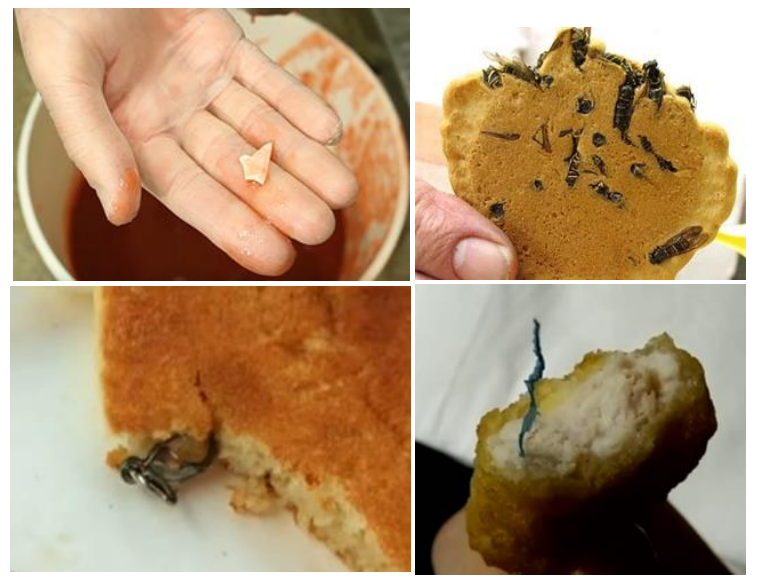

Picture 1 Foreign bodies in Food (Incidents annual report, 2018)

\section{MATERIAL AND METHODS}

\section{Evaluation of foreign particles using RASFF notifications}

We analysed the presence of foreign bodies using notifications in the Rapid Alert System for Food and Feed (RASFF) during the years 2016, 2017 and 2018. All research information was obtained from the RASFF web portal. The records we obtained using the portal and weekly reports contained the following information: - the classification of the given notification, whether it was an alert, border rejection, information, information for attention or information for followup;

the date of the specific notification of a foreign body in food; 
- the notifying country;

the object (foreign body) contained in contaminated food (metal, glass, plastic, wood, etc.);

the specific product in which a foreign body was found (biscuits, cheese, walnuts, etc.)

the food commodity in which the product is included (cereals and bakery products, milk and dairy products, convenience foods, etc.);

the risk decision classified as serious, not serious or undecided.

Regarding the evaluation of the whole reference period, we compared the number of notifications in the RASFF in individual years and we also evaluated notifications based on the type of a foreign body, food commodity and the type of a notification. We divided these data according to notification localisation into Eastern, Northern, Southern and Western Europe. At the same time, we statistically calculated the p-value for individual data to see if there was a difference in the data obtained.

The specific reference period was chosen to compare our results with the scientific article published by Djekic et al. (2017). This article describes an analysis of the presence of foreign bodies using data from the RASFF database in the period 1998 - 2015. We compared our data with the authors' data and subsequently established trends in the presence of foreign bodies for the reference period.

In the last part, we dealt with the comparison of the presence of foreign bodies in respect of all monitored risks using the RASFF database.

Table 1 The incidence of foreign bodies in Europe for the years 2016, 2017 and 2018

$\begin{array}{lccc}\begin{array}{l}\text { Country presence of foreign } \\ \text { bodies }\end{array} & \text { The number of presence of foreig } \\ \text { bermany } & 2016 & \text { year } 2017 & 2018 \\ \text { Netherlands } & 31 & 25 & 28 \\ \text { Great Britain } & 13 & 11 & 16 \\ \text { Italy } & 12 & 10 & 12 \\ \text { France } & 11 & 15 & 10 \\ \text { Sweden } & 9 & 8 & 16 \\ \text { Denmark } & 8 & 3 & 5 \\ \text { Austria } & \mathbf{8} & 20 & 21 \\ \text { Ireland } & 7 & 4 & \mathbf{8} \\ \text { Belgium } & 5 & 1 & 1 \\ \text { Finland } & 3 & 4 & 10 \\ \text { Spain } & 2 & 1 & 7 \\ \text { Slovenia } & 2 & 2 & 4 \\ \text { Malta } & 0 & 0 & 3 \\ \end{array}$

There were 128 notifications in 2016, Slovakia reported the presence of foreign bodies only once. Regarding our country, the notification involved glass fragments in chicken liver and the risk was classified as serious. Slovakia was also associated with one notification from Estonia, where a caterpillar was found in tomato sauce, which had been made in our country. However, this notification was classified as not serious. In 2017 there were 128 reports as well. Again, Slovakia made one notification of the presence of foreign bodies in food. This case involved sharp fragments in a canned cod. The year 2018 saw the most notifications for the whole reference period, namely 153. In Slovakia, no notification of the presence of foreign bodies was reported that year.

Table 2 Subjects of foreign bodies in the years 2016, 2017 and 2018

The number of presence of foreign bodies

Items foreign bodies in pieces (year)

$\begin{array}{lccc} & 2016 & 2017 & 2018 \\ \text { pests } & \mathbf{3 4} & \mathbf{2 9} & \mathbf{1 9} \\ \text { glass } & \mathbf{2 7} & \mathbf{2 9} & \mathbf{3 2} \\ \text { metal } & \mathbf{2 6} & \mathbf{2 5} & \mathbf{3 6}\end{array}$

Table 3 Presence foreign bodies in food commodities in 2016, 2017 and 2018

\begin{tabular}{|c|c|c|c|c|c|c|c|}
\hline \multirow[t]{2}{*}{$\begin{array}{l}\text { Food } \\
\text { commodities }\end{array}$} & \multicolumn{3}{|c|}{$\begin{array}{l}\text { The number of } \\
\text { presence of foreign } \\
\text { bodies in pieces } \\
\text { (year) }\end{array}$} & \multirow[t]{2}{*}{$\begin{array}{l}\text { Food } \\
\text { commodities }\end{array}$} & \multicolumn{3}{|c|}{$\begin{array}{l}\text { The number of } \\
\text { presence of foreign } \\
\text { bodies in pieces } \\
\text { (year) }\end{array}$} \\
\hline & 2016 & 2017 & 2018 & & 2016 & 2017 & 2018 \\
\hline $\begin{array}{l}\text { fruits and } \\
\text { vegetables }\end{array}$ & 23 & 21 & 16 & poultry & 4 & 4 & 6 \\
\hline $\begin{array}{l}\text { cereals and } \\
\text { bakery } \\
\text { products }\end{array}$ & 20 & 24 & 28 & $\begin{array}{l}\text { herbs and } \\
\text { spices }\end{array}$ & 4 & 2 & 1 \\
\hline $\begin{array}{l}\text { intermediate } \\
\text { products }\end{array}$ & 13 & 15 & 17 & alcohol & 3 & 0 & 1 \\
\hline $\begin{array}{l}\text { milk and } \\
\text { milk } \\
\text { products }\end{array}$ & 12 & 7 & 14 & $\begin{array}{l}\text { fish and } \\
\text { their } \\
\text { products }\end{array}$ & 3 & 6 & 6 \\
\hline nuts and & 9 & 9 & 8 & ice cream & 2 & 2 & 3 \\
\hline
\end{tabular}

To evaluate the data acquired and find differences in them, we used the Chisquare test using the $\mathrm{R}$ program. The $\mathrm{p}$-values calculated to determine if there was a difference in our data are given in the tables included the study itself. Pvalues were determined for each line in the tables to see if there were differences in the given data within European regions in the number of foreign body notifications. We also determined p-values for each column of the table and thereby came to the conclusion on whether there were any differences across the whole analysed group in one European region. If the p-value is less than 0.05 there is a difference in the data; if it is greater than 0.05 , there is no difference in the data.

\section{RESULTS AND DISCUSSION}

\section{Evaluation of RASFF data for the period 2016 - 2018}

When evaluating notifications of the presence of foreign bodies from the RASFF for the years 2016, 2017 and 2018, we found a total of 409 notifications reported to the RASFF system. In analysing these three years, we first focused on the very evaluation of RASFF notifications. We evaluated three specific areas, namely which countries most notifications came from, what foreign body was most frequently found in food, and what food commodity had the most frequent presence of foreign bodies.

Country presence of
foreign bodies
Norway
Lithuania
Romania
Poland
Greece
Switzerland
Iceland
Slovakia
Estonia
Luxemburg
Czech Republic
Hungary
Portugal
Croatia

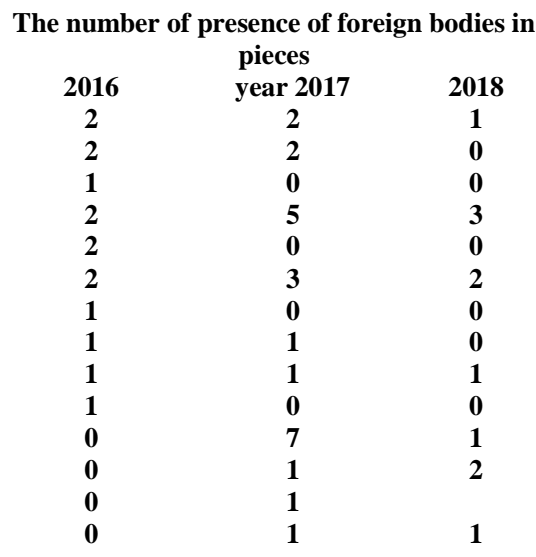

$\begin{array}{lccc}\text { plastic } & 24 & 27 & 49 \\ \text { rubber } & 4 & 1 & 0 \\ \text { stone } & 2 & 4 & 1 \\ \text { wood } & 1 & 4 & 0 \\ \text { paper } & 0 & 1 & 0 \\ \text { bones } & 0 & 0 & 1 \\ \text { other } & 10 & 8 & 15\end{array}$

In 2016 the most reported types of foreign bodies in Europe were pests (34 pieces), glass (27 pieces), metal (26 pieces) and plastic ( 24 pieces). Furthermore, there were objects such as rubber ( 4 pieces), wood (1 piece) or stone ( 2 pieces). We classify as others such items that were found in low numbers and in 2016 these included, for example, rodent faeces, part of a slicer or electric cable, hard glue parts, batteries and foam structure. In 2017 and 2018 the most frequently reported foreign bodies were glass, pests, plastic and metal.

seeds

\begin{tabular}{|c|c|c|c|c|c|c|}
\hline soups, sauces & 7 & 4 & 3 & $\begin{array}{l}\text { honey and } \\
\text { royal jelly }\end{array}$ & 1 & - \\
\hline $\begin{array}{l}\text { cocoa, tea, } \\
\text { coffee }\end{array}$ & 7 & 4 & 4 & $\begin{array}{l}\text { cephalopods } \\
\text { and } \\
\text { products } \\
\text { thereof }\end{array}$ & 1 & 2 \\
\hline $\begin{array}{l}\text { meat and } \\
\text { products } \\
\text { thereof }\end{array}$ & 7 & 4 & 8 & additives & 1 & 0 \\
\hline other & 6 & 10 & 11 & $\begin{array}{l}\text { diet, } \\
\text { fortified } \\
\text { foods }\end{array}$ & 0 & 2 \\
\hline confectionery & 5 & 10 & 14 & $\begin{array}{l}\text { non- } \\
\text { alcoholic } \\
\text { drinks }\end{array}$ & 0 & 2 \\
\hline
\end{tabular}


The number of reports in the period 2016 - 2018 had increasing character. In 2016 it was 128 reported in 2017 and again 128 in 2018 to 153 reports of the presence of foreign bodies in foods. Visual display of messages is presented in the graph in Figure 1.

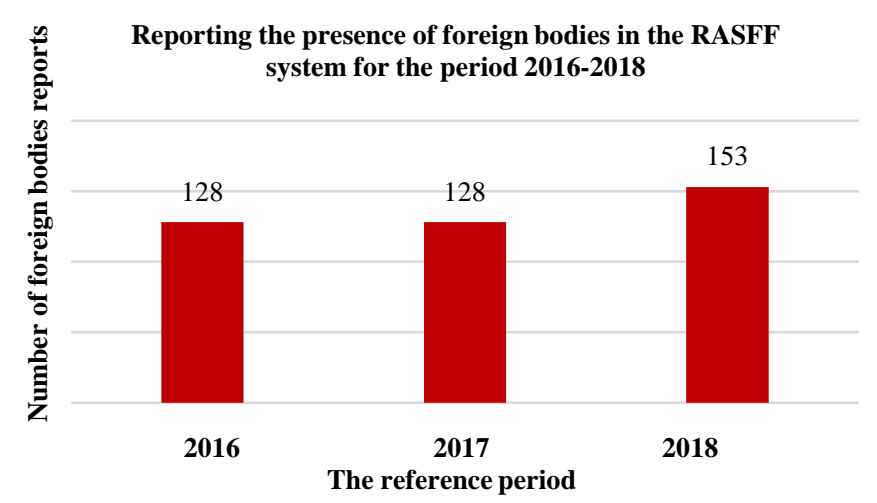

Figure 1 Graphical representation of reports of foreign bodies in the database RASFF in the period 2016, 2017 and 2018.

Djekic et al. (2017), with whom we compared our data, based the subject analysis of the presence of foreign bodies on RASFF notifications for the years 1998 - 2015. Altogether 1,446 notifications of foreign bodies were reported over this reference period. In this article the authors collected data on the presence of foreign bodies before 2006 into one category, analysing each year separately from that year.

By combining our data and the data on the presence of foreign bodies given by Djekic et al. (2017), we created a chart to find out what trend is typical of the presence of foreign bodies according to notifications in the RASFF for the period $1998-2018$. The trend line points to the fact that the number of notifications from a 20-year perspective is slightly decreasing. However, we can observe an annual increase in the number of foreign body notifications from 2013.

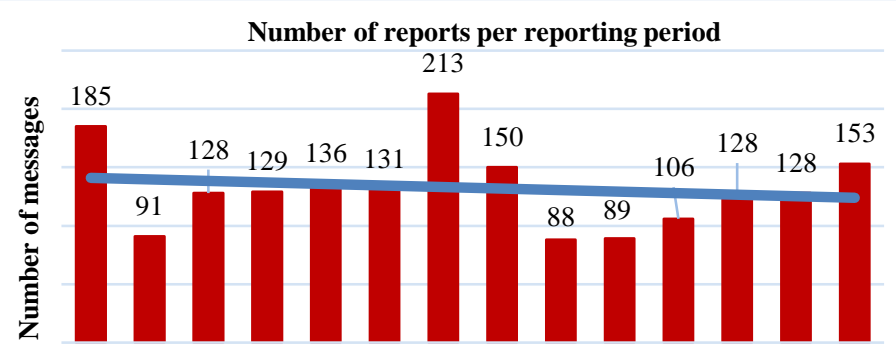

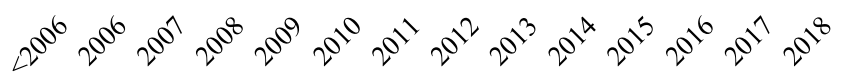

The reference period

Figure 2 The number of reports of foreign bodies in the RASFF in the period $1998-2018$

\section{Presence of foreign bodies in European regions}

When analysing the presence of foreign bodies in the Rapid Alert System, we also looked at the frequency of presence with respect to individual European regions. We divided the territory of Europe according to regions into Eastern, Northern, Southern and Western Europe. Based on the number of notifications, we dealt with division - according to the type of a foreign body, food commodity and the type of a notification. At the same time, we also present the p-value of the Chi-square test in the relevant tables, which indicates whether or not there is a difference in the values found. If the p-value is less than 0.05 , it means that there is a difference in the data, and vice versa, if it is greater than 0.05 , there is no difference in the data.

The numbers of notifications based on the type of a foreign body are presented in Table 4. Differences in the number of notifications and European regions were found in the case of foreign bodies of glass, metal, pests, plastic, rubber and others. In these cases, the p-value was less than 0.05 . Regarding the difference in types of foreign bodies within one region, differences in the number of notifications were found in all 4 regions. By comparing the absolute values of the number of notifications, we can state that glass, metal, and plastic were most prevalent in Western Europe and pests and rubber were most commonly reported in Northern Europe. The group of foreign bodies classified as others, which were present in low numbers and which included e. g. glue, thermometer, part of a slicer or a human tooth, were most frequently reported in Western Europe.

In their article Mattos et al. (2016) identified the most common types of foreign bodies - grain fragments, insects and its larvae, dead mites and rodent faeces. The presence of particles such as metal, glass or wood, which can seriously damage human health, was reported as rare. Aguiar et al. (2018) identified the most significant foreign bodies in milk - insects, hair, plastic, metal and fabric. In their article Djekic et al. (2017) stated that, based on their research in 1998 2015, pests, glass and metal were the most common types of foreign bodies. In our analysis for the years 2016 - 2018, plastic, glass, metal and, to a considerable extent, also pests were most frequently reported. Further, in their research Djekic et al. (2017) found that glass and metal were most commonly reported in Western Europe, pests in Eastern Europe and plastic, rubber and wood in Northern Europe. As for the foreign bodies of glass, metal and the group of others, our results are consistent with their analysis. The difference was mainly in the case of pests and plastic, which in our reference period were most frequently present in other parts of Europe than those reported in the article with which we compared our results.

It is an interesting fact that metal as a foreign body is still one of the most frequently reported items in spite of the extensive introduction and use of metal detectors in food processing plants. In their article Losito et al. (2011) reported on research pointing out that the nonuse of metal detectors in food processing plants is one of the greatest risks in food safety.

Table 4 The presence of foreign bodies in regions of Europe with regard to the type of foreign bodies

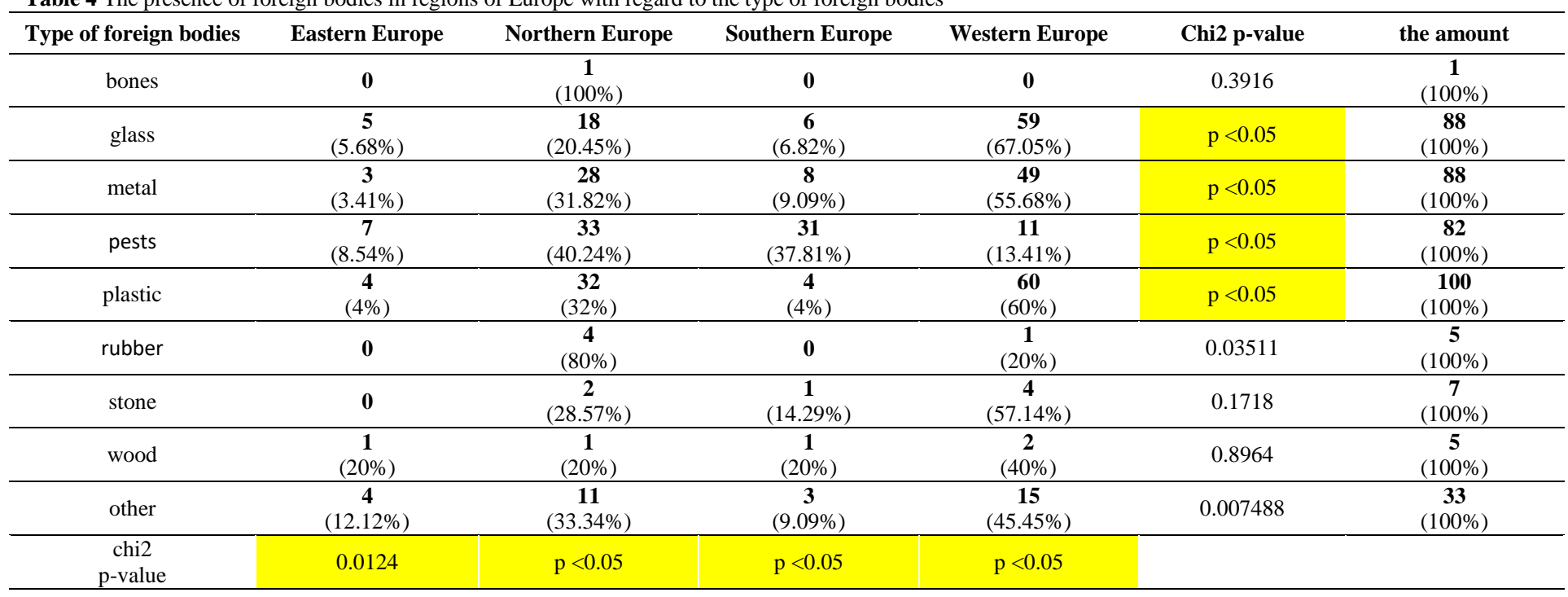


The division of food commodities into individual European regions based on the number of notifications is shown in Table 5. By calculating the p-value of the Chi-square test, we found that there was a difference in the number of notifications and the regions from which these notifications came in the case of meat, milk and dairy products, fruit and vegetables, bakery and confectionery products, convenience foods as well as in the group of others. When comparing individual food commodities within one European region, there was no difference apart from Eastern Europe. According to Djekic et al. (2017), notifications regarding meat came most frequently from Western Europe, fruit and vegetables were most frequently reported in southern countries and bakery and confectionery products in Northern Europe. According to our results, the only notifications that correspond with the article are those regarding meat, which came most frequently from Western Europe. For the period 2016 - 2018, fruit and vegetables and bakery and confectionery products were most frequently reported in Western European countries. In the aforementioned article by Djekic et al. (2017) the most frequently reported items for the presence of foreign bodies in the reference period were fruit and vegetables, nuts and seeds and bakery and confectionery products. In our case, bakery and confectionery products ranked first in the number of notifications, followed by fruit and vegetables and convenience foods also showed a higher number of notifications. In the research conducted by Mattos et al. (2016) in 2001 - 2015, bakery and confectionery products also ranked first with regard to the presence of foreign bodies in food. In their publication Edwards and Stringer (2007) identified three categories of products that were most commonly reported in association with the presence of foreign bodies. These were fruit and vegetables, nuts and seeds and bakery and confectionery products. Our results confirmed that the most commonly reported food commodity was bakery and pastry products, fruit and vegetables, which is consistent with the assertion in the article. However, in our analysis the commodity of nuts and seeds with the number of notifications 26 ranked next to last of the commodities examined.

Table 5 The presence of foreign bodies in the regions of Europe due to food commodities

\begin{tabular}{|c|c|c|c|c|c|c|}
\hline Food commodities & Eastern Europe & Northern Europe & Southern Europe & Western Europe & Chi2 p-value & the amount \\
\hline beverages & $\begin{array}{c}\mathbf{1} \\
(11.12 \%)\end{array}$ & $\begin{array}{c}\mathbf{4} \\
(44.44 \%)\end{array}$ & 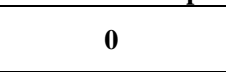 & $\begin{array}{c}\mathbf{4} \\
(44.44 \%)\end{array}$ & 0.129 & $\begin{array}{c}\mathbf{9} \\
(100 \%)\end{array}$ \\
\hline meat & $\begin{array}{c}\mathbf{4} \\
(12.12 \%)\end{array}$ & $\begin{array}{c}\mathbf{1 2} \\
(36.36 \%)\end{array}$ & $\begin{array}{c}\mathbf{1} \\
(3.04 \%)\end{array}$ & $\begin{array}{c}16 \\
(48.48 \%) \\
\end{array}$ & $\mathrm{p}<0.05$ & $\begin{array}{c}\mathbf{3 3} \\
(100 \%) \\
\end{array}$ \\
\hline milk and milk products & $\begin{array}{c}\mathbf{1} \\
(3.04 \%)\end{array}$ & $\begin{array}{c}\mathbf{1 1} \\
(33.33 \%) \\
\end{array}$ & $\begin{array}{c}\mathbf{3} \\
(9.09 \%) \\
\end{array}$ & $\begin{array}{c}\mathbf{1 8} \\
(54.54 \%) \\
\end{array}$ & $\mathrm{p}<0.05$ & $\begin{array}{c}\mathbf{3 3} \\
(100 \%) \\
\end{array}$ \\
\hline fruits and vegetables & $\begin{array}{c}\mathbf{2} \\
(3.33 \%)\end{array}$ & $\begin{array}{c}\mathbf{1 7} \\
(28.33 \%)\end{array}$ & $\begin{array}{c}\mathbf{1 8} \\
(30 \%)\end{array}$ & $\begin{array}{c}\mathbf{2 3} \\
(38.34 \%)\end{array}$ & $\mathrm{p}<0.05$ & $\begin{array}{c}\mathbf{6 0} \\
(100 \%)\end{array}$ \\
\hline nuts and seeds & $\begin{array}{c}\mathbf{4} \\
(15.38 \%)\end{array}$ & $\begin{array}{c}8 \\
(30.77 \%)\end{array}$ & $\begin{array}{c}\mathbf{6} \\
(23.08 \%)\end{array}$ & $\begin{array}{c}\mathbf{8} \\
(30.77 \%)\end{array}$ & 0.6386 & $\begin{array}{c}\mathbf{2 6} \\
(100 \%)\end{array}$ \\
\hline pastry and confectionery & $\begin{array}{c}\mathbf{5} \\
(6.95 \%) \\
\end{array}$ & $\begin{array}{c}\mathbf{2 5} \\
(34.72 \%) \\
\end{array}$ & $\begin{array}{c}\mathbf{1 4} \\
(19.44 \%) \\
\end{array}$ & $\begin{array}{c}\mathbf{2 8} \\
(38.89 \%) \\
\end{array}$ & $\mathrm{p}<0.05$ & $\begin{array}{c}\mathbf{7 2} \\
(100 \%) \\
\end{array}$ \\
\hline intermediate products & $\mathbf{0}$ & $\begin{array}{c}\mathbf{9} \\
(20 \%) \\
\end{array}$ & $\begin{array}{c}\mathbf{1} \\
(2.22 \%)\end{array}$ & $35(77.78 \%)$ & $\mathrm{p}<0.05$ & $\begin{array}{c}\mathbf{4 5} \\
(100 \%) \\
\end{array}$ \\
\hline other & $\begin{array}{c}\mathbf{7} \\
(5.34 \%) \\
\end{array}$ & $\begin{array}{c}\mathbf{4 4} \\
(33.59 \%) \\
\end{array}$ & $\begin{array}{c}\mathbf{1 3} \\
(9.92 \%) \\
\end{array}$ & $\begin{array}{c}\mathbf{6 7} \\
(51.15 \%) \\
\end{array}$ & $\mathrm{p}<0.05$ & $\begin{array}{c}\mathbf{1 3 1} \\
(100 \%)\end{array}$ \\
\hline $\begin{array}{c}\text { chi2 } \\
\text { p-value }\end{array}$ & 0.06439 & $\mathrm{p}<0.05$ & $\mathrm{p}<0.05$ & $\mathrm{p}<0.05$ & & \\
\hline
\end{tabular}

Regarding individual types of notifications and their incidence within European regions, differences based on p-values were found in the notification type, except for information for follow-up. In addition, when comparing all types of notifications for each region, we found that there were differences in these data The numbers of notifications for individual notification types are listed in Table 6.

Djekic et al. (2017) found that for the period 1998 - 2015 alerts were most frequently reported and prevailed mainly in Western and Northern European countries. We came to the same conclusions in our study. According to them border rejections were reported mainly in Eastern European countries, but we found that in our reference period border rejections had been reported mainly in Southern Europe. In addition, according to our findings, information notifications were most prevalent in Western Europe and information notifications for attention were most frequently reported in Northern and Southern Europe with the same incidence.

Table 6 The presence of foreign bodies in the regions of Europe due to the type of notification

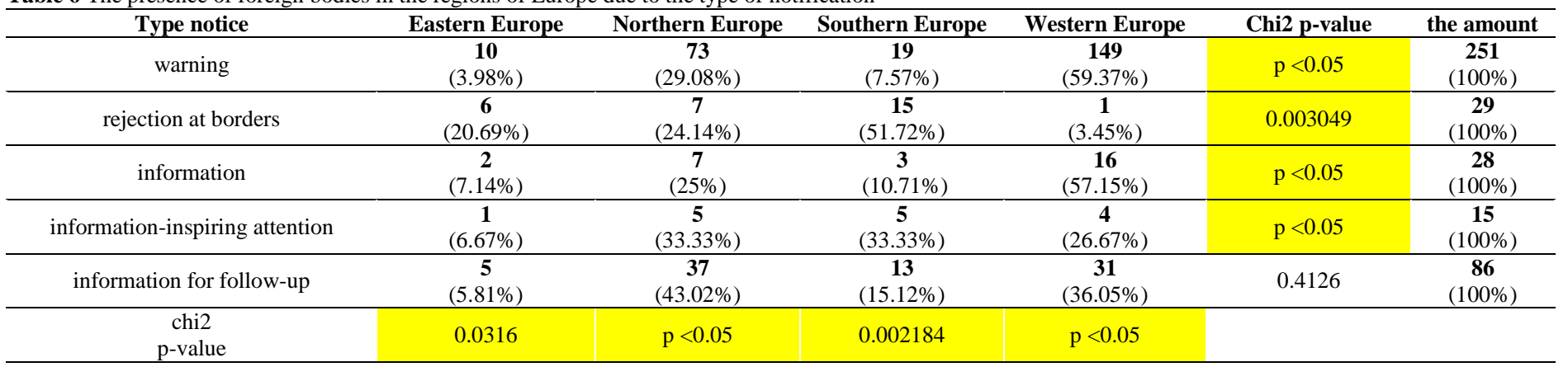

We distinguish three types of risk decisions - serious, not serious and undecided. During the 2016 - 2018 reference period, serious risk was present in $63.6 \%$ of cases, not serious in $23 \%$ of cases and undecided only in $13.4 \%$ of cases (Table 7). In their analysis of the years 1998 - 2015. Djekic et al. (2017) reached substantially different results. Most of the risks were classified as undecided $(78.3 \%)$, than came risks which were not serious $(11.8 \%)$ and the least frequent risk decisions were serious $(9.9 \%)$.

Table 7 The decision on risk for the period $2016-2018$

\begin{tabular}{ccc}
\hline The decision on risk & $\begin{array}{c}\text { The number of reports } \\
\mathbf{2 0 1 6}-\mathbf{2 0 1 8}\end{array}$ & $\%$ \\
\hline seriously & 260 & $63.6 \%$ \\
\hline minor & 94 & $23 \%$ \\
\hline undecided & 55 & $13.4 \%$ \\
\hline
\end{tabular}


other categories. The cases of market withdrawals that are more dangerous and more frequently happening are related to mycotoxins or the presence of microorganisms or pesticides in food.

According to the 2006 - 2015 annual reports published by the UK Food Standards Agency (FSA) (Incidents Annual Report, 2018), the amount of foreign bodies ranges from $4 \%$ to $10 \%$ relative to other risks. The highest percentage of foreign bodies was in 2006 , namely $10.34 \%$. Since that year, values have been declining annually, while in recent years we have observed an insignificant increase and decrease in values representing the presence of foreign bodies in food in the range of $4-6 \%$. Again, these data confirm that the presence of foreign bodies in food cannot be completely eliminated. As this value does not increase significantly, the measures that are used to control the presence of foreign bodies in food are properly applied.

Table 8 The number of reports of all kinds of risks RASFF database

\begin{tabular}{|c|c|c|c|c|c|c|}
\hline & \multicolumn{2}{|c|}{2016 (year) } & \multicolumn{2}{|c|}{2017} & \multicolumn{2}{|c|}{2018} \\
\hline & $\begin{array}{l}\text { count } \\
\text { reports }\end{array}$ & $\%$ & $\begin{array}{l}\text { count } \\
\text { reports }\end{array}$ & $\%$ & $\begin{array}{c}\text { count } \\
\text { reports }\end{array}$ & $\%$ \\
\hline food adulteration / fraud & 114 & $3.71 \%$ & 184 & $4.77 \%$ & 86 & $2.30 \%$ \\
\hline allergens & 113 & $3.67 \%$ & 144 & $3.73 \%$ & 168 & $4.49 \%$ \\
\hline biological contaminants & 43 & $1.40 \%$ & 51 & $1,32 \%$ & 46 & $1.23 \%$ \\
\hline chemical contaminants (other) & 1 & $0.03 \%$ & 0 & $0.00 \%$ & 3 & $0.08 \%$ \\
\hline incorrect composition & 174 & $5.66 \%$ & 153 & $3,96 \%$ & 217 & $5.80 \%$ \\
\hline environmental pollutants & 51 & $1,66 \%$ & 39 & $1.01 \%$ & 53 & $1,42 \%$ \\
\hline feed additives & 3 & $0.10 \%$ & 1 & $0.03 \%$ & 4 & $0.11 \%$ \\
\hline additives & 168 & $5.46 \%$ & 178 & $4.61 \%$ & 177 & $4.73 \%$ \\
\hline foreign bodies & 134 & $4.36 \%$ & 131 & $3.39 \%$ & 168 & $4.49 \%$ \\
\hline GMO & 15 & $0,49 \%$ & 16 & $0.41 \%$ & 13 & $0,35 \%$ \\
\hline metals & 218 & $7.09 \%$ & 279 & $7.23 \%$ & 181 & $4.84 \%$ \\
\hline new food & 78 & $2.54 \%$ & 178 & $4.61 \%$ & 51 & $1.36 \%$ \\
\hline industrial contaminants & 9 & $0,29 \%$ & 8 & $0,21 \%$ & 24 & $0.64 \%$ \\
\hline incorrect labeling & 28 & $0,91 \%$ & 28 & $0.73 \%$ & 51 & $1.36 \%$ \\
\hline migration & 78 & $2.54 \%$ & 63 & $1.63 \%$ & 79 & $2,11 \%$ \\
\hline natural toxins & 26 & $0,85 \%$ & 29 & $0.75 \%$ & 32 & $0.86 \%$ \\
\hline mycotoxins & 549 & $17.85 \%$ & 579 & $15.00 \%$ & 655 & $17.51 \%$ \\
\hline pathogenic microorganisms & 261 & $8.49 \%$ & 260 & $6.74 \%$ & 331 & $8.85 \%$ \\
\hline other & 7 & $0,23 \%$ & 9 & $0,23 \%$ & 11 & $0,29 \%$ \\
\hline organoleptic aspects & 41 & $1,33 \%$ & 30 & $0.78 \%$ & 33 & $0.88 \%$ \\
\hline faulty packing & 25 & $0.81 \%$ & 31 & $0.80 \%$ & 31 & $0.83 \%$ \\
\hline parasites & 23 & $0.75 \%$ & 41 & $1.06 \%$ & 41 & $1,10 \%$ \\
\hline pathogenic microorganisms & 505 & $16.42 \%$ & 870 & $22.54 \%$ & 782 & $20.90 \%$ \\
\hline pesticide residues & 251 & $8.16 \%$ & 337 & $8.73 \%$ & 278 & $7.43 \%$ \\
\hline lack of control & 97 & $3.15 \%$ & 115 & $2.98 \%$ & 136 & $3.64 \%$ \\
\hline process contaminants & 3 & $0.10 \%$ & 23 & $0.60 \%$ & 13 & $0,35 \%$ \\
\hline radiation & 5 & $0.16 \%$ & 11 & $0.28 \%$ & 14 & $0.37 \%$ \\
\hline residues of veterinary medicinal products & 47 & $1.53 \%$ & 64 & $1.66 \%$ & 49 & $1.31 \%$ \\
\hline TSE & 8 & $0.26 \%$ & 8 & $0.21 \%$ & 14 & $0.37 \%$ \\
\hline THE AMOUNT & 3075 & $100 \%$ & 3860 & $100 \%$ & 3741 & $100 \%$ \\
\hline
\end{tabular}

\section{CONCLUSION}

By analysing the presence of foreign bodies in different European regions (Eastern, Northern, Southern, Western Europe), we found, by means statistica evaluation, that there were differences in some of the data obtained with respect to the country reporting a foreign body. We found that plastic, glass and metal were most commonly reported in Western Europe, pests and rubber in Northern Europe. As far as the food commodity is concerned, bakery and confectionery products, fruit and vegetables and convenience foods belonged to the most frequently reported and the notifications came most often from Western Europe Notifications from this part of Europe were made in respect of other monitored commodities as well. Regarding the notification type, the most frequent one was an alert and, in the case of a risk decision, serious risk constituted the largest part. The last task in evaluating the presence of foreign bodies in the RASFF system was to determine the proportion of foreign bodies in respect of all other risks reported to the RASFF. Based on our analysis, we judge that in each reference year the proportion of foreign bodies was around $4 \%$, which represents a relatively significant value.

Acknowledgments: This research was supported by KEGA 017SPU-4/2019.

\section{REFERENCES}

Aguiar, R., Esmerino, E., Rocha, R., Pimentel, T., Alvarenga, V., Freitas, M., Silva, M. \& Cruz, A. (2018). Physical hazards in dairy products: Incidence in a consumer complaint website in Brazil. Food Control, 86, 66-70. https://doi.org/10.1016/j.foodcont.2017.11.020
Ansari-lari, M., Soodbakhsh, S., Lakzadeh, L. (2010). Knowledge, attitudes and practices of workers on food hygienic practices in meat processing plants in Fars, Iran. Food Control, 21(3), 260-263. https://doi:10.1016/j.foodcont.2009.06.003 Bouzembrak, Y., Marvin, H. J. P. (2016). Prediction of food fraud type using data from Rapid Alert System for Food and Feed (RASFF) and Bayesian network $\begin{array}{llllll}\text { modelling. } & \text { Food } & \text { Control, } & 61, & 180 & -\end{array}$ https://doi.org/10.1016/j.foodcont.2015.09.026

Codex Alimentarius. (2014). Discussion Paper on the Need for a Revision of the General Principles of Food Hygiene (CAC/RCP 1-1969) and its HACCP Annex Prepared by Finland with input from New Zealand and the United States. Available

http://www.fao.org/tempref/codex/Meetings/CCFH/ccfh46/CRDs/FH46 CRD02 e.pdf

Djekic, I., Jankovic, D., Rajkovic, A. (2017). Analysis of foreign bodies present in European food using data from Rapid Alert System for Food and Feed (
RASFF).
Food
Control,
79
143-149.

https://doi.org/10.1016/j.foodcont.2017.03.047

Edwards M. (2014). Food hygiene and foreign bodies. In Lelieveld, H. L. M., Holah, J. T., Napper, D. Hygiene in Food Processing. 2nd ed. Cambridge, UK : Woodhead publishing, 441-464. ISBN 978-0-85709-429-2. https://doi.org/10.1533/9780857098634.3.441

Edwards M. C., Stringer, M. F. (2007). Observations on patterns in foreign material investigations, The Breakdowns in Food Safety Group. Food Control, 18, 773-782. https://doi.org/10.1016/j.foodcont.2006.01.007

European Union. (2015). Better HACCP implementation/Final overview report the state of implementation of HACCP in the EU and areas for improvement Luxembourg : Publications Office of the European Union, 38, ISBN 978-92-7943526-3. https://doi.org/10.2772/59374 
European Union. (2017). RASFF - The Rapid Alert System for Food and Feed 2016 annual report. Luxembourg : Publications Office of the European Union, 39, ISBN 978-92-79-68052-6. https://doi.org/10.2875/022237

European Union (2018). RASFF - The Rapid Alert System for Food and Feed 2017 annual report. Luxembourg : Publications Office of the European Union, 58, ISBN 978-92-79-80317-8. https://doi.org/10.2875/404601

Gomes-Neves, E., Cardoso, C. S., Araújo, A. C., Correia Da Costa, J. M. (2011).

Meat handlers training in Portugal: A survey on knowledge and practice. Food Control, 22(3-4), 501-507. https://doi.org/10.1016/j.foodcont.2010.09.036

Goodwin, D. (2014). Foreign body contamination and the implications for the food manufacturing sector. New Food Magazine, issue: 2 , https://www.newfoodmagazine.com/article/13789/foreign-body-contaminationand-the-implications-for-the-food-manufacturing-sector/ Incidents annual report. (2018). In Food Standards Agency. https://www.food.gov.uk/about-us/reports-and-accounts

Jianu, C., Golet, I. (2014). Knowledge of food safety and hygiene and personal hygiene practices among meat handlers operating in western Romania. Food Control, 42(0), 214-219, https://doi.org/10.1016/j.foodcont.2014.02.032

Losito, P., Visciano, P., Genualdo, M., Cardone, G. (2011). Food supplier qualification by an Italian Large-scale-Distributor: Auditing system and non-

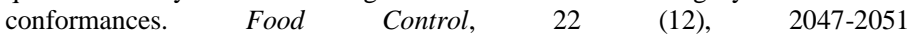
https://doi.org/10.1016/j.foodcont.2011.05.027

Mattos, E. C., Daros, V. S. M. G., Dal Col, R., Nascimento, A. L. (2016).

Occurrence of foreign matter in Food: Applied identification method-association of official agricultural Chemists (AOAC) and food and Drug Administration (FDA). International Journal of Biological, Biomolecular, Agricultural, Food and Biotechnological Engineering, 10(3), p.101-105, https://doi.org/10.5281/zenodo.1111855

Panchal, P. K., Bonhote, P., Dworkin, M. S. (2013). Food safety knowledge among restaurant food handlers in Neuchatel, Switzerland. Food Protection Trends, 33(2), 133-144. Available at: http://www.foodprotection.org/files/foodprotection-trends/May-13-Panchal.pdf

Pichler, J., Ziegler, J., Aldrian, U., Allerberger, F. (2014). Evaluating levels of knowledge on food safety among food handlers from restaurants and various catering businesses in Vienna, Austria 2011/2012. Food Control, 35(1), 33-40. https://doi.org/10.1016/j.foodcont.2013.06.034

RASFF. (2019). Rapid alert system for food and feed (RASFF). In D. g. f. h. a. c. protection (Ed.). Brussels, Belgium: European Commision.

RASFF Portal. 2019. https://webgate.ec.europa.eu/rasff-window/consumers/

Sun, Y.M., Wang, S.T., Huang, K.W. (2012. Hygiene knowledge and practices of night market food vendors in Tainan City, Taiwan. Food Control, 23 (1), 159 164, https://doi.org/10.1016/j.foodcont.2011.07.003

Svrcinova, P., Tomášková, H., Janout, V. (2019). Risk associated with foreign bodies in food in the Czech Republic. Potravinarstvo Slovak Journal of Food Sciences, 13(1), 301-307. https://doi.org/10.5219/1069 